\title{
Ethnologies
}

\section{Gringo/a as Sociolinguistic Fractal}

\section{Stephanie C. Kane et Harriet E. Manelis Klein}

Volume 35, numéro 1, 2013

URI : https://id.erudit.org/iderudit/1026449ar

DOI : https://doi.org/10.7202/1026449ar

Aller au sommaire du numéro

Éditeur(s)

Association Canadienne d'Ethnologie et de Folklore

ISSN

1481-5974 (imprimé)

1708-0401 (numérique)

Découvrir la revue

Citer ce document

Kane, S. C. \& Manelis Klein, H. E. (2013). Gringo/a as Sociolinguistic Fractal. Ethnologies, 35(1), 3-27. https://doi.org/10.7202/1026449ar

\section{Résumé de l'article}

Pour les anthropologues qui effectuent leur travail de terrain en Amérique latine, le terme polysémique " gringo " traduit inévitablement un processus de négociation de l'identité culturelle. En s'appuyant sur les expériences d'interactions des auteurs dans la poursuite de leurs objectifs professionnels, cette article montre comment la nation, la religion, le sexe, la race, de même l'histoire de la colonisation, de la migration, et des alliances émergent et s'estompent dans les rencontres kaléidoscopiques entre des stéréotypes hémisphériques et des voyageurs interculturels. Les récits entrelacés de l'expérience personnelle du " gringo-hood " que nous présentons révèlent le caractère fractal de la connaissance et de l'expérience. Cet article montre ainsi comment les interactions linguistiques, culturelles, et surtout folkloriques traduisent différentes dimensions de nos expériences socialement situées, de même que les différentes formes de discours que nous avons croisés.
Ce document est protégé par la loi sur le droit d'auteur. L'utilisation des services d’Érudit (y compris la reproduction) est assujettie à sa politique d'utilisation que vous pouvez consulter en ligne.

https://apropos.erudit.org/fr/usagers/politique-dutilisation/ 


\title{
Gringo/A as Sociolinguistic Fractal
}

\author{
Stephanie C. Kane and \\ Indiana University \\ Harriet E. Manelis Klein \\ Stony Brook University
}

\section{Introduction}

Gringo is a polysemic term that anchors gender and orients toward a mythic historical relationship of unequal power between nations and regions. Its semantic domain precedes any individual ethnographer entering the field and is generally activated (even if the term is not used explicitly) when the ethnographer has left a home base in the northern hemisphere and is moving through ethnographic sites in the southern hemisphere. The projection of the term onto individuals, freighted as it is with derogatory associations, often produces dismay or frustration in the person so framed. At first, it may seem unjust that one is identified with an ideological paradigm that one has devoted oneself to critiquing. Then, one is forced to come to terms with the privilege one inhabits by virtue of one's passport, independently of one's conscious beliefs and actions.

Within its semantic field is the central frame of the United States as an arrogant regional power. U.S. power is conferred on any ethnographer who by appearance, language, style, race, or religion indexes the U.S. to people in Latin America. Yet, in his description of Mexico after 1775, Américo Paredes (1958: 8-9) indicates how the disparaging character of the term had already become quite divorced even from the personal appearance of speakers:

In succeeding generations the Indians, who began as vaqueros and sheepherders for the colonists, were absorbed into the blood and the culture of the Spanish settlers. Also absorbed into the basically Spanish culture were many non-Spanish Europeans, so that on the Border one finds men who prefer Spanish to English, 
who sometimes talk scornfully about the "Gringos," and who bear English, Scottish, Irish, or other non-Spanish names.

Although the position or perspective of those who use or experience the word can be subtle, in contemporary parlance, the gringo referent usually includes Canadians, Australians, Europeans, mostly white, Christian, English speakers who come from somewhere else with some money to spend. In short, the diversity of human categories in its embrace contrasts with the term's homogenizing force. In use, however, the homogenizing force is clearly split by gender. Adams (1999: 114) defines gringa uniquely as:

\begin{abstract}
[A] figure found throughout Latin America, whose dark powers derive from the unstable intersection of the North/South hierarchy with the power relationship of the male/female hierarchies. The gringa embodies exclusive boundaries, and, at the same time, the tantalizing possibilities of border crossing alliances.
\end{abstract}

As we consider the meaning of gringo/a through our fieldwork experience, we find also that religion, or more particularly our Jewish cultural identity, inevitably inserted into a Christianinflected religious frame, also becomes key to disrupting the term's operation in any given cultural exchange. By making our Jewishgringa-fieldworker selves an object of analysis, we reveal how the process by which mythic qualities of the gringo/a intertwine with our personal experience, and hence our fieldwork narratives. Our aim is to show how the manner and effects of this intertwining are sociolinguistically complicated by gender, ethnic and religious identity. ${ }^{1}$ And so the word gringo/a mediates our relationships and our stories, changing shape and meaning even as it renders gringohood anew. Looking back, we see ourselves moving through a Latin American landscape of sociolinguistic fractals. We propose that the fractal pattern of language produced through a uniquely powerful word has implications for thinking anew about the dynamics of and variations in folklore texts and their collection. In addition, this essay contributes to the folklore of fieldwork, as carried out by folklorists or anthropologists (Reuss 1974).

1. For the analytic role of the self in fieldwork and boundary folklore (Paredes 1977; Kane 1988, 1992; Klein 1999; Stoeltje et al. 1999; Kahn 2003). 


\section{The Power of Language}

Gringo is a word. It is a living organism which grows, changes shape and significance as it is used, influencing the universe in which it is spoken. This word is capable of simultaneously producing multiple variations while maintaining its basic lexemic shape. As a result the word "gringo" is always recognizable.

Approaching gringo-hood in terms of language as we do can only be understood in the context of culture contact, a process that intensifies with globalization. The nature of the contact and the contrast can vary enormously, but most of it is verbal, part of a speech event. As anthropologists, our experience of and with this term is not the same as authors, journalists, or visiting lecturers; it is not so much about shunning behavior. The term varies in its use (and implications) depending on the ideologies of those in contact and the space of social interaction. Yet gringo-hood is always symbolic of a type of otherness that is conceptualized in terms of a spatialized (north/south) contrast.

Spatial patterns in nature triggered Mandelbrot's (1977) conceptualization of non-geometric families of shapes as fractals -irregular and fragmented forms that are oddly consistent in their repetition across scales (in this sense, fractal contrasts with modular design). ${ }^{2}$ We apply the fractal concept to gringo-hood because it changes shape as we move in and out of membership in a variety of social categories and groups. Interestingly, the word "gringo" by itself is not concrete as a beach, a snowflake or a leaf might be; yet it becomes real through the power of language.

In studying the word's power, we find that spoken contrast, or distinction between gringo and not-gringo, or gringo/a, actually projects an opposition that may be salient at different levels of relationship (Irvine and Gal 2000: 38 cited in Gal 2005). In other words, it is a fractal:

... [a] distinction that can be reproduced repeatedly by projecting it onto narrower or broader comparisons. Fractal recursions are repetitions of the same contrast but at different scales ... With each

2. Cited in the Oxford English Dictionary (OED) definition of /fractal/. See also Diaz (1990) for a fractal analysis of a Hindu cosmology. 
recursion, one changes the perspective of the viewer/interpreter and hence the scope of comparison (Gal 2005: 27).

We link this elaboration of the fractal character of gringo identity formation to foundational work in anthropological linguistics. For example, Paul Kroskrity (2001: 106) noted, "Identities may be linguistically constructed both through the use of particular language and linguistic forms ... associated with specific national, ethnic, or other identities." We can also define ourselves as Penelope Eckert and Sally McConnell-Ginet (1992) did by noting that we participate in communities that are composed of individuals who are temporarily unified through shared participation in fieldwork activities and thus we are able to shift our identities as researchers, females, Jewish women, and non-Latinas from moment to moment. In linguistic terms, this means that we continue to define the boundaries of words included in, and excluded from, our shared identity complex: gringos/gringas/Jews/field researchers.

\section{A Note on Method: Linking Words to Fractals in Folklore}

In Myth and Meaning, Lévi-Strauss (1979: 39-41) analyzes the quality of repetition or redundancy in stories of a clan's past; his analysis foreshadows the way we discuss the fractal character of gringo/a vignettes that are at once social history and myth:

\footnotetext{
"This, of course, could be a historical event, but if we look closely at the way it is explained, we see that the type of event is the same, but not exactly the details. ... So, you see, we have an explanatory cell. Its basic structure is the same, but the content of the cell is not the same and can vary; so it is a kind of mini-myth if I may say so, because it is very short and very condensed, but it has still the property of a myth in that we can observe it under different transformations. When one element is transformed, then the other elements should be rearranged accordingly."
}

We build on Lévi-Strauss's method of structural analysis of myth and history, while opening it to "the structure of conjuncture" (Marshall Sahlins 1981: 68) characteristic of the imperial northsouth confrontations encoded in the gringo/a term. Each one of our personal experience narratives are both "mini-myths" and explanatory cells that allow us to explore the kinds of negotiations we engage in 
when we are labeled and treated as gringas, paying particular attention to the reflexive politicization of our persons.

In some cultural locations, the word 'gringo/a' releases a notquite-human, supernatural figment of social imagination. Rising vampirically from a ripped and bloodied semantic terrain, its criminally arrogant smile-grimace supports a long waxed curl of blond mustache evoking both cipher and cliché. Of course, individuals fit more or less easily into the cliché. For example, as Caucasian women, neither of us have mustaches; Kane is blondish whereas Klein is dark haired. We are academically different generations and at the time of the early fieldwork episodes, Kane was single while Klein was married with children. From our memories of years past, we pull vignettes that represent a series of negotiations with perceptions of gringo/a-hood.

Part of a fractal experience, Kane and Klein's co-authorship has an academic origin story which then evolved through a series of migrations and alliances. They met in 1983 at a linguistic anthropology conference on Native South American Discourse at the University of Texas at Austin, and then informally at a party Vera Mark organized to introduce Klein to a small group of women graduate students. For Kane and Klein, their mutual interest in Latin America, in fun and laughter and food and guys, and being Jewish gringa anthropologists, has kept their intellectual pursuits from being overly cerebral.

The narrative cores, or scripts, capture interactions that are clear in our minds either because we repeated them in oral retelling or because they were simply too strange to forget. Although some experiences appear in fieldnotes and correspondence, for the most part they have been left out of published writings. The folklore figures in the narrative cores are ourselves as seen by those we studied, by those whom we were trying to get permission to study, or those with whom we serendipitously came into contact. Even in reflexive modes, in the fullness of our other formal writing, we excluded most of this gringa material as either anomalous or supplementary to our main foci, more autobiographical than ethnographic or linguistic. Here, however, the autobiographical character of the material allows us to trace shifting contexts over long time periods and wide transnational 
terrain. We organize the small corpus typologically by communicative function.

We begin with culture brokers who invoke the gringo specter to block access to research sites or materials, where passage depends on our skills in spinning, evading, joking or preempting the term. We contrast and follow the boundary-making and breaking experiences with experiences of engagement, wherein productive interaction relies on a more nuanced use (and deepening irrelevance) of personalized gringo-hood in ways that can mobilize exploratory discussion in personal/professional networks. The locales are in Brazil, Paraguay, Panama, Belize and Argentina. Various predicaments and surprises dramatize gringo-hood as a sociolinguistic fractal, which shift meaning metaphorically as our gender, ethnic, and anthropological identity-complex moves in and out of focus and across scales of social interactions.

\section{Gargoyles and Gatekeepers: Historical Precedents and Animating Boundaries}

1849: "We were hooted and shouted at as we passed through, and called 'Gringoes'."3

1956: "Soon some poor children from the second-class bus pointed at me and whispered 'Gringa'. 4 ... Restraining my gringa impatience once more I stood and laughed at them." 5

Gringo/a is like an epithet. It is invoked to simultaneously set apart different cultural identities and to establish boundaries. While it can be used to note seemingly neutral childlike distinctions, e.g., "She can't possibly understand, she needs to learn 'our meaning," spoken-word 'gringo' can, and often does, emphatically communicate the contempt of colonized for colonizer. Even while expressively diverse, the label homogenizes political left and right, offering no distinctions between e.g., peaceniks and CIA operatives. Even with ironic affection or curiosity, no one likes being called gringo. The

3. OED. /gringo/ 1849 J. W. AUDUBON Western Jrnl. (1906) 13 June 100

4. OED /gringa/ D. MATHEWSON Down Mexico Way i. 6.

5. Ibid. 11 . 
labeled may succumb to secondary deviance, feeling implicated in the evils emanating from gringo empire. ${ }^{6}$ Once the name is spoken, the listener named, the receiver has an ethical obligation to recognize its rude truth and recall-or learn-the brutal history of how our privileges as U.S. passport bearers were, and continue to be, established.

The gringo figure rode out of the violent history of Mexican-U.S. relations. Yet Kane remembers hearing it first from a fellow traveler riding a bus through Afghanistan in 1973, where it mysteriously casts suspicion on naive adventure. Most commonly, however, gringo emerges in social interactional settings including Central and South American inhabitants and Anglo-seeming foreigners. Klein recalls hearing it early in her first Latin American experience living in Bolivia.

\section{National Identity}

\section{Klein 1961 Bolivia}

As I was crossing a street probably in a way similar to the way New Yorkers cross streets, a man yelled "gringa" at me. Not to let on that I was indeed a gringa, I cursed him in Arabic, utilizing language my father had accidentally provided me with when I was growing up in a multilingual household. I was told that Arabic curses are wonderfully descriptive and can rarely be understood, especially when said by women who are not expected to know that form of verbal behavior.

The utterance 'gringo/a' is a speech act, meant to warn, contain, or mock. Like a chick from its shell, one must crack out of the category inscribed on one's person to communicate properly. It forces labeled persons to come to terms with the imperialist crimes that historically underpin our comforts, our ability as anthropologists, for example, to temporarily exile ourselves as a form of professional activity. Coming to terms with/as a gringo may be an appropriate starting point for sincere conversation; in other registers, cracking through a gringo shell requires some trickery, like aiming a joke at a cultural fault line.

6. According to Lemert's (1975: 354) criminological theory, secondary deviance occurs when the labeled internalizes the label and begins to identify with it. 
As real persons labeled gringos move about-doing, writing, making, inhabiting this name, we improvise discordantly. From whispered intimacies to disembodied messages zipping around digital clouds, 'gringo/a' uttered pivots the tracks of inter-cultural conversation. Spoken-word 'gringo' invokes a parody of intertwining historical struggles, the strands circling in upon themselves like a rope in the musty corner of a dimly lit room. ${ }^{7}$

Metaphoric variations of the meanings of gringo-hood can be used for political advantage or subterfuge. As fieldworkers learn the implications of gringo variations, they may resituate themselves. The next vignette signaling nationality will be recognizable to many readers.

Klein 1970s Argentina

I was told that I was better off putting a Canadian patch on my backpack than an American one, since that would make me "not such a bad gringa.

\section{Sex and Gender Identity}

As field researchers who have spent most of our careers working in Central and South America, we have had many opportunities to appreciate gringo's polysemic power. And yet in truth, we are not gringos but gringAs, a variant that, at its best, bestows an uncanny ability to slip in and out of the gendered space within gringo's semantic domain and, at its worst, traps a person (depending on age and status) in a(n) (a)sexualized body. Gringas can play on men's desires with benign powers, annoyance, or danger. But if a gringa is perceived to be lacking in her context-specific gendered performance, for instance, if she is perceived to be bestowing sexual favors on non-gringo men from the lower classes in colonized settings, she is subject to disciplinary gazes, imputations of whoredom or criminality from moral entrepreneurs. In other words, crossing out of the gringo category for sex has distinct repercussions for women and men; women more quickly lose social and legal privileges accompanying

7. To explain the way we all use commonsense theory in a unstable way, Pfohl (1994: 11-12) uses the example of walking into a dark room and seeing a snake, which upon turning on the light, turns out to be a garden hose. 
gringo-hood when they don't appropriately contain desires (Kane 1992, Starr 2003). At best, such cross-category relationships tend to be dismissed as a form of sexual tourism. As "gendered enclosure" (Nencel 2001), cross-categorizations constrain real women and structure the social imagination more generally. Symbolically, gringas, like blacks, are constitutive elements in the reproduction of racialized and sexualized logic.

Not only is the gringa, as image and person, sexualized, but she can be treated as a he, a she/he shape-shifter (Adams 1999: 121-2), a marginal male (Shelemay 1991). The gringa can be an object of both rejection and desire, a pawn, a prostitute, a conquest (Paredes 1978: 197 cited in Eysturoy 1990: 25-6). Klein's experience in Argentina and Panama splits her bodily rituals from her communicative, professional self (as, in one way or another, we suppose, we all do).

\section{Klein 1971-1978 Argentina:}

My experience, however, was that as a gringa, unlike a local female, I could have dinner alone in a restaurant in the provinces and not be considered open to sexual encounters. During my fieldwork on the Toba language in the Argentine Chaco, I worked with consultants who lived in small indigenous enclaves situated at the periphery of semi-urbanized towns. Usually I stayed in small hotels which served breakfast, but the rest of my meals required me to find places to eat which served an itinerant clientele. ${ }^{8}$

\section{Klein 1982 Panama:}

Another experience, perhaps due to my liminal nature as a married gringa anthropologist, occurred in my field work among the Ngobe (better known as Guaymi). In 1982 I was teaching a linguistic field methods course to a group of priests and nuns in a mountainous area in the province of Tole, Panama. I was considered female when it came to bodily needs such as bathing or urinating or defecating, but I was considered part of the male universe when it came to dining (and imbibing) and housing arrangements.

The next vignette shows how the spoken word gringo perverts an inter-cultural conversation from money to sex.

8. This fieldwork resulted in my doctoral dissertation and numerous other publications listed on my webpage: www.linguistics.stonybrook.edu/visitors/ harriet.klein 


\section{Kane 1983 Panama}

My first time in the Darién, and I hadn't gone deep in; I stayed in a village on the road, half Emberá and half Wounaan. ${ }^{9}$ Shortly after my arrival, following the advice of the village headman, the son of the Old Man, I asked if I might accompany him whilst he collected medicinal plants. We left at dawn the next day. Leaving the village, we sat at the bus-stop for a moment and he said he would charge me $\$ 50$ for the knowledge of each plant. This was the going rate for gringos, he said. ${ }^{10}$ No way, I say, I don't have that kind of money and that's not really the focus of my project, as he dropped the price to $\$ 25$. So we went onward and I watched; he said little if anything. Before leaving the forest for the open field again, he suggested we rest by a small pool, whereupon he suggested that perhaps I would be willing to trade sex for samples. The old crow!

\section{Religious Identity}

Also inescapable, religion shapes gringa myth and personal experience. ${ }^{11}$ As it happens, Kane and Klein do not fit squarely in the

9. One would not notice the difference from dress, architecture or cooking styles; but their languages, though linguistically close, were mutually unintelligible. They spoke to each other and Kane in Spanish.

10. For example, the Old Man might have been referring to a comprehensive medicinal plant collecting helicopter tour that was carried out as part of a Lawrence Livermore project assessing the feasibility of using a nuclear explosion to clear a bigger, wider Panama Canal through the Darién (see Lindsay-Poland 2003: 81-84).

11. I (Kane) carried out ethnographic fieldwork in recently formed villages in the Darién rainforest among the Emberá and Wounaan Indians. Many had not been out of the forest and if they had seen a gringa at all, it would have been a missionary wife. I continually had to distinguish myself from missionary wives, as a skewed form of religious politeness would compromise social interaction. I would clarify my religious difference by explaining that I did not believe there was a little man with a long white beard in the sky, in effect distinguishing myself as a secular, non-Christian person, not necessarily as a Jewish person. The distinction was sufficient for people to feel free to share with me a fuller range of mythical motifs, e.g., the foundational anti-hero with a taste for menstrual blood, who was erased from versions told to missionaries (Kane 1988). In subsequent writing (Kane 1994/2004), I intentionally crossed or blurred boundaries between the empirically knowable and unknowable, verifiable but interpretable. I think of this as a kind of counter-gringo maneuver that resists rearranging co-produced knowledge into hierarchical organization marking off theirs/ magical, ours/scientific. 
center of either gringo/a category, which along with speaking English and having pockets full of cash, includes Christianity as a salient feature. Because since the Conquest and still today Jews have figured so bizarrely in the missionaries' foreign-peopling of Latin American social and mythical imagination, surprises occur. As Jewish gringas, we have an irresistible ability and sometimes defensive necessity to use our anomalous existence to confound expectations. Our composite identities as gringos/gringas/Jewish/anthropologists, have variously come to the fore as we pursued research goals, whether we were searching for native Toba speakers in the Gran Chaco or tree frogs in the Xingu. (Klein is a linguistic anthropologist and Kane was an ecologist before discovering cultural anthropology and folklore.)

Klein 1977-1978 Paraguay and Brazil:

I self-identified as an anthropologist, because linguists are closely identified with the Summer Institute of Linguistics (SIL), and a few other evangelical missionary groups, and their role in Christianizing the native population always lurked in the background.

From the perspective of our research counterparts, our empirical existence as fully human may be far from clear, even as we proceed with systematic scholarly inquiry. This is not to say that we are always pushed way out to imaginary edge-zones of colonial encounter where horned creatures, dwarfs with backwards feet (duendes), or Death itself in a body with no liver lurk. Nevertheless, possibilities of dangerous transactions exist. And between the forces of development and war emanating from distant realms, suspicion of gringos' full humanity continually renews itself. None of this necessarily signifies a lack of desire for spoils of war or development. Hence ambivalence, tentative hopefulness, and a reliance on magical discourse, mark exchanges (Kane 1994/2004).

\section{Professional Barriers (Hostilities)}

The magical-real may contribute to gringo-strangeness and to hostile political environments that affect anthropologists seeking entrance to fieldwork spaces. 
When I first went into the field in 1971, I did so with grants from the US government and with letters indicating the scope of my dissertation project. A part of the introduction to fieldwork overseas is the need to touch base with the players in the country one is going to work in. Accordingly, I made an appointment to see the professor I had been told was working on an analysis of the Toba language. Minutes into our conversation I was told by that investigator that he had done all the work on the Toba language and that I should go home and work on North American indigenous languages. Of course, I didn't follow his advice and began my fieldwork through contacts with other scholars and indigenous consultants.

\section{Klein 1978 Brazil:}

Another moment of hostility occurred when I was attempting to get permission from the Brazilian agency that controlled access to the indigenous reservations. I had been told that permission had been granted and that the permission would be radioed to the chefe do posto (head honcho on the reservation). However, when I arrived on foot at the reservation, I was placed under house arrest on the Kadiweu reservation for 48 hours because the permission had not been received. When finally clearance, via radio, was confirmed, I was told that I could only work with the oldest resident, a woman without any teeth, because since I was a gringa and not a native speaker of Portuguese, my not understanding her speech wouldn't matter. And, in this case, I really did not get as much work done as I could have. ${ }^{12}$

On the other hand, regional class distinctions can move a gringa into a preferred position.

Klein [1972] Argentina:

As a gringa I was accepted as a preferred investigator compared to local anthropologists. Because Spanish was not my first or second language, and I felt that communication was more important than impeccable grammatically correct sentences, I did not correct the provinciano accent or any grammatical errors in Spanish by my consultants. At one point when I was working in Resistencia in Chaco province, I was accompanied by a local anthropologist from Buenos Aires who was interested in how the elicitation process works. On our first day there, she interrupted our conversation

12. Actually, I did get enough data and with the work of others was able to present a paper entitled, "Comparative Toba-Kadiweu Semantics. Linguistic Society of America meetings, December 1979. 
and kept correcting the Spanish of my Toba consultant. Finally, my consultant told me in Toba to get rid of my 'friend'.

Trapped by the image of gringo as bandit, Kane was refused "official" entrance to fieldwork in the Amazon.

\section{Kane 1980 Brazil:}

Through pure serendipity, and without much lead time, I got funding to record bird songs and tree frog calls in the Amazon for my Masters thesis. My advisor, Dr. Blair, sent me to Dr. V in the Museum in São Paulo to get permission. I don't remember Blair's exact words but I do remember Dr. V's. He stood and cried out as he waved his arms furiously around his head: "Blair! That Bandit! That Saboteur!" He continued the tirade condemning Blair for not sharing properly, perhaps a valid complaint from Dr. V's point of view, I cannot say. Upon my request that he grant my permission despite the misunderstanding, he sent me on a wild goose chase through the city's tangled traffic to get signatures from scientists who were all on vacation.

So I began my journey without official permission. From Ceará to Belem to the Xingu, everywhere I attempted to set up base camp, something would happen: an emergency (a man run over by a truck was saved by the mud his organs were pressed into and had to be carried out through the forest and put on a passing bicycle to get to the hospital; a woman was bitten by a snake) or my equipment would conspire to fail at the most impossible moments. Eventually, I thought, 'No enough, I must work at a proper field station.' An overloaded ferry crisscrossed with layered hammocks brought me from Altamira to Manaus whilst everyone asked me if I was going, as they were, to see the visiting Pope. In Manaus, I worked through official channels for three months, patiently establishing the required paper trail to get permission to do research. I remember the day the last letter was to be signed. As I approached what I thought would be the last step toward acceptance, the man who was meant to sign off on my research plan emerged from a building with whom else but Dr. V. When Dr. V saw me and realized that I had circumvented him, he yelled: "How dare you! You gringos think that you can do anything you want!" After that, I gave up and went to have fun in Rio.

As Kane hoped to begin her dissertation research, she entered a different historical configuration, where a subcategory of the gringo/a identity rose to salience as an obstacle. 
Kane 1985 Panama:

I arrived in Panama City in hopes of meeting Emberá leaders and confirming permission to work in a Darién village just as they were mobilizing an international conference of indigenous peoples. Now in this venue, it was not about gringos not getting in, because gringo missionaries were allowed (a woman from the Baha'i faith took me under her wing during this episode). In this venue, it is gringo anthropologists who were not welcome, or more accurately, who figure specifically, ideologically as reviled (most strongly among representatives of northern first nations). Neither my gender nor ethnicity (Jewish and American from New York via Russia and Hungary) could tilt me out of the anthropology category because this was indeed an ethnographic project. I succeeded in my struggle to get official permission with a combination of agony and fierce string pulling, i.e., both questioning and making full use of my gringo-hood. Eventually, I was granted permission to first go to the smallest, furthest upriver, most traditional village, away from all the Christian contests between evangelicals and Catholics. I eventually got to live in a more central village, which is where I recorded the two personal experience narratives that became the title of my book The Phantom Gringo Boat (Kane 1994/2004).

\section{Tribal Myths: Jews in the Christianized Imaginary}

Lévi-Strauss (1967) believed that all myths were one myth because, like language, its deep structure is wired into neural networks. No matter how strange at first hearing, at some level of analysis all myths are thus translatable, decodable. We think the gringo myths we present here are unified by their power to pull us into narrative orbit, even if we don't share belief in basic assumptions. When Favreet Saadat (1980) studied witchcraft in the French Bocage, despite the fact that she was carrying out an empirical investigation, she was pulled into the supernatural web that her neighbors and subjects spun. We too were trapped by gringo empire past and present. Trapped, but not without verbal art, which appears here in accidental, conscious, unconscious forms.

\section{National and Cultural/Religious Identities}

\section{Klein 1982 Panama}

The mythic web of biblical history enters here perhaps. In 1980,

I was asked by a friend, a Jesuit anthropologist, how to assist a 
community of priests and nuns who were involved in helping a group of Ngobe deal with some multinational corporations and the Panamanian government, who were interested in developing a copper mine (Cerro Colorado) on the Ngobe land. The language spoken by these people has a very difficult vowel system and the clergy who were trying to help were unable to make headway in understanding, let alone speaking, Ngobere. My friend thought that if I taught a field methods course in the field to both the priests and the nuns, perhaps they would gain some knowledge about the language's sound system and its grammatical structure, thereby making it easier for them to learn the language. However, in order to teach the course I had to get permission from the bishops of the two provinces involved in this learning project. ${ }^{13}$ I wrote to the bishops explaining that first of all I was an American, that I was a female, a gringa, and that I was Jewish. Their immediate response was that there was no problem with my working with their colleagues; after all, the woman they revere the most was Jewish. ${ }^{14}$

And so Klein's entry was founded on a disconcerting premise, a misalignment perhaps of the meaning of the (Jewish) Blessed Mother to Jews as opposed to Christians. A similar misalignment of meaning, though not falsity, accompanies Klein's use of the image of tribe.

Klein 1979 Paraguay:

The next Jewish story takes place on a field trip to survey the indigenous languages of Puerto Casado a port town in the western part of the country where there were five different linguistic and cultural indigenous groups living. I was asked to what tribe I belonged. Solidarity was achieved when I indicated that I belonged to the tribe of Israel.

In Historical Metaphors and Mythical Realities, Marshall Sahlins (1981: 6) wrote:

"[T] he world may not conform to the presuppositions by which some people talk about it. In the event, speech brings signs into "new" contexts of use, entailing contradictions which must be in turn encompassed by the system. Value is truly constituted in a system of signs, but people use and experience signs as the

13. These are the same clergy referred to earlier.

14. This course held in three sessions totaling five months over the period of two years resulted in the printing of the Manual Provisional de Nga'bere, a combined effort of the clergy and Klein. 
names of things; hence they condition and potentially revise the general conceptual values of linguistic terms and relations by reference to a world. The encounter with the word is itself a valuation, and a potential revaluation, of signs."

In the next vignette, Klein embodies an encounter with the word "Jew" and her imaginary horns.

Klein 1974-1979 (Argentina and Paraguay):

In the more remote Chaco areas that I traveled in, when I was asked what religion I belonged to - the expected answer being Christian, or evangelical, or Catholic - and answered that I was judia or hebrea, the immediate reaction was a move to feel the horns on my head. They were always disappointed that there weren't any. The question was posed by both indigenous leaders and my language consultants. Of course, the action of someone actually feeling my scalp - a creepy kind of feeling - led to teachable moments where I could correct erroneous and ancient dogma brought to the New World by the Spanish clergy and still repeated in the 21 st century.

Polysemic words create logical conundrums, especially where gender, religion, and nationality are involved. Among Jews, the confounding power of being a gringo/a may fade in significance, outweighed by other commonalities. Often more salient, however, are the logical properties of being a gringa, that is:

\section{A Gringa $=$ a kind of Gringo (but)}

A Jew does not (necessarily) $=$ a kind of Gringo

When part of a group, a gringa is commonly subsumed under the term gringo(s), losing gendered meaning [as in (wo)man]. But in general, women can usually be visually identified in a crowd of people called gringos. Womanhood, however flexible, is an embodied term. ${ }^{15}$ In contrast, one's Jewishness-except from within sartorially marked orthodox enclaves or when generated as racist/anti-Semitic stereotypes-can stand hidden in the light. In other words, Jews have more of a choice to hide/reveal their identity than do women. Technically, in short, we propose that a Jew can be fully American,

15. We realize that gendered appearance can be quite plastic, and is, of course, among lesbians, transgendered folk, and transvestites. It is the contrast between embodied signs of gender versus Jewishness that we wish to draw out here. 
but never fully a Gringo, because a basic element of Gringo-hood is Christian.

\section{Shenanigans in Urban Gringo Enclaves}

The meaning and authority of gringo/a identity reproduces itself through official and everyday practices which shape social imaginaries, paradoxically moderating and exacerbating the negative projections upon persons.

Klein 1972 Argentina:

When I started my initial language fieldwork in Argentina, I worked with some urban speakers of Toba in the city of Buenos Aires. My language consultants regularly came to my apartment, sometimes one of them, sometimes three. A few months before I left to return to the United States, the apartment I had rented went into foreclosure. It turned out that the landlord had not deposited my rent money to cover his mortgage, but instead used it to pay for an apartment for his mistress. The bank insisted on my cooperation in allowing open houses for potential buyers and the hanging of a sign from the balcony-both actions being distressing and inconvenient for me. As the final month of my rental contract drew near, I decided not to pay the last month's rent. I was advised that it was unlikely that I would get my security deposit back without a legal battle. And so, since I wouldn't pay the last month, the landlord retaliated by initiating a lawsuit against me. His grounds were that because I had all kinds of people [indios] coming into the apartment, I was running a brothel. And wasn't that a terrible thing for a gringa to be doing?

The advantage of being a gringa, though, was that I was able to utilize the United States Embassy for legal advice and a quick end to the suit resulted, with my being able to clear my name as a gringa Madame.

\section{Kane 1984 Panama}

The gringos controlled a large swath on both sides of the Panama Canal and the U.S. Southern Command for all Central and South America was deep inside a giant hill overlooking the Pacific edge of Panama City. A Panamanian colleague told me disdainfully that gringos always run to the zone whenever they are afraid some political thing might be going wrong. (His disdain did not interfere with his right hand that repeatedly slipped off the car's gearshift onto my knee before groping up my leg in the mercifully 
short drive to a discussion group.) I'd gone to the Fort Clayton Army Base to get maps. A cartographer told me that when I came to the city on break from the upriver forest, I could avoid my rather hefty pensión bills by staying on the base. I'd come in for one or two weeks every six or seven weeks, whenever I ran out of food upriver. I met a jumpy Special Forces guy who boasted of his prowess, miming how he picked up men by their necks and slit them open from neck to balls with a machete. The best time was when I shared the women's dorm with a group of Puerto Riqueña soldiers who hung out in the common areas dancing, laughing, living joyfully. Technically, as Latinas from a colonized island, I suppose they were not gringas, but they were in the gringo army.

It is possible to realign interests and play with identities, lending the advantages of gringo-hood to others.

\section{Kane 2007 Brazil}

They wanted to show me the neighborhood hangout where they cavorted with friends and lovers in their youth. Called 'The Holes' after two small coves set below the promontory facing the Atlantic Ocean. For Río Vermelho neighborhood people, the drive provided the only access to the beach and the panoramic view. Middle-aged women by this time, Iza's sister said gleefully, "Today we don't have to ask permission because she (pointing to me) is a Gringa and does not have to ask." The fact was, my being a Gringa happened to be convenient for us all this afternoon although we all realized its underlying unfairness even as we played its game. As we sat on the promontory facing the sea, we talked about how racism is unconscious. ${ }^{16}$

\section{Migrations and Alliances: Ancestral Fractals}

Although it was scholarship and friendship that brought us together, we both have Jewish ancestry. As we got more deeply into analyzing our fieldwork experiences for this essay, the salience of Jewish culture emerged in surprising and serendipitous ways. We came to understand both personally and analytically that when we enter fields-of anthropology, of fieldwork-we do so with preexisting structures and with their potential for agency and surprising alignments and collaborations. Here, the sociolinguistic gringa fractal catches Kane in the Port City Project as she does a walking tour.

16. See a more detailed version of this excerpt in Kane (2012: 70-71). 
Kane 2007 Brazil

As we walked through the historic port area of Recife one early January day, my friend Iza spoke of the Jews' role in Recife's history: Escaping the Spanish inquisition, Jews in the $17^{\text {th }} \mathrm{C}$. helped build an island port in the city of Recife but left when the Dutch were defeated by the Portuguese. A small group moved to help found the commercial center on an island in another port city, Manhattan. Many others moved to different islands in the Caribbean and some to Surinam, for example.

This is Iza's way of talking about our mutual history, of mediating our identities by subtly shifting the historical referents away from PanLatin American interpretive frame of gringo-hood. As artist and city planner, she conceptualized sequential Jewish settlements as fractals. Like the forms of rivers and snowflakes whose fractal patterns repeat in space and across scales, these two mercantile centers of port cities founded by Jews are socially as well as geographically fractals; for Iza, repeated experiences. ${ }^{17}$

Jewish mercantilism as a fractal:

If I (Kane) think of my relationship to a Jewish ancestral past, it follows the linear splitting branch of a tree whose genetic roots are elsewhere; this past inheres fully to the movement of escape away from pogrom-riddled places. So, my ancestral past is ruptured. And even though I recently learned from my cousin that families in Russia and Israel doing Internet genealogy found us, the "lost branch" who left for Philadelphia and New York, I do not reach out. I'd rather think in an Izarian way in terms of fractals: my past a fractal relationship of infinite belonging to an ancestral Jewish past, like sand shapes on a busy shore carved by waves and feet. Iza, in conversation created this way of imaging her past so that it overlaps with mine, deepening our empathic connection. On that day in the ancient port by the first synagogue in the "New" world, the Jew in me takes precedence over the gringa, which releases me temporarily from the burden of gringo-hood. Interrupted by war, the Jews from Recife went to New York, where centuries later my grandparents landed and successfully entered into the garment trade and other businesses on the island of Manhattan. Or (fantasizing now), I could animate an imagined relationship with the Jewish traders who established the spice trade in Cochin, Kerala, India in the 15th Century in a creative, open project to animate fractal relationships that assume various forms in port

17. 2 January, 2007. Kane's field note typescript, p. 128 
cities, islands, enclaves of mercantile trade, cultural intersections among fictive and genealogical families.

Like most New Yorkers, I think of myself as a New Yorker, no matter where I live now or where my ancestors originally came from. And unless I travel, or go a movie, the spoken word gringo/a won't often come up. It only becomes pertinent at key moments such as the day I am walking in Salvador da Bahia where Iza and her sister grew up.

Klein's family experienced a shared history but a dramatically different trajectory.

Klein 1965 Argentina

German/English-Spanish:

In the 1920's, one of my mother's sisters and her husband and one of my mother's brothers and his wife made their way to Argentina. They all came from a small town in Germany, near the Dutch border, where for centuries the family had been cattle farmers. My aunt's husband continued the tradition, first by living and working on the rural Baron de Hirsch estates in Entre Rios, but eventually by becoming a butcher settling in a town outside of Buenos Aires. My uncle began the same trajectory but quickly decided to become an urban dweller and then worked in a steel factory, thereby abandoning the long tradition.

In 1965, while I was living in the province of Buenos Aires, my mother, who had not seen her siblings and their families for over forty years, came to Buenos Aires to visit me and my family. The siblings had a wonderful reunion at which my major role was as a translator. What had transpired in the forty years of basic non-communication was that the Argentine relatives mixed their German with Spanish and my mother mixed her German with English. I recall sitting in the back of a limo, which took my mother from the airport to my uncle's house, with my head swiveling from my mother to her brother, from her brother back to my mother, each asking me to translate or explain in English or Spanish, what the other was saying. It was great fun, and as a linguist, it was interesting to see which words (not so much grammatical constructions) were so different.

I (Kane) have to return to the peculiarity of being a Jew and a Gringa. As a granddaughter of immigrants, I was trained to engage flexibly with contradiction, e.g., we kept kosher in the house but were allowed to eat ham sandwiches outside. Bubbe and Zayde left the 
little Ukranian village of Kibblitch days before everyone was killed in a pogrom. As far as I'm concerned, that past is as unwanted as the bad card reading I got once in midtown Manhattan. But travel I must and as I do, I carry the political unconscious of a Jew, always honing and transacting escape routes. And if I travel, as is my wont, in Central, South America and the Caribbean, I will continue encountering myself as a gringo fractal. Encouraged as a child to reach for all things American except Christianity (especially humor, food, a passion for social justice), Gringos were as far from the model in my grandparents' minds as Texas is from the Lower East Side. So, on some level, I find Klein and myself here tasked with reconciling callings, identities, attributions.

Bubbe cookies:

As Klein had spent a good part of her career in the region, before I left for the field in 2006, I asked her for contacts in Buenos Aires. She gave me the names of a couple, friends, who lived in the city, were Jewish, and had also spent time on a university campus in the U.S. Lovely and gracious hosts, they invited my husband and me to their art-filled flat a number of times for dinner. One time, to my astonishment, we were offered exactly the kind of plain, diagonally-cut cookies that my grandmother used to make in large aluminum pans: Bubbe Cookies!, a Russian Jewish food that, in my mind, typifies the mundane celebration of family life. In a rush of perception, like a time machine delivery to Bubbe's kitchen table, belly over-full, cousins laughing, my father spreading jam on the always too-dry cookies and sipping tea, while my mother, her sister and Bubbe argue in Yiddish about something in which we children have no interest. Little did the matriarchs know then that I would be mistaken for a Gringa one day! Happy would they be to know that I would grow up to be an itinerant word merchant with the power to choose how to be or not to be a Gringo/a.

Here we work backwards from the vignette where bubbe cookies connected Kane to our non-gringo friends in Argentina, to relate how Klein's connection to our friends (Ana and Sanni) started. The combination of friendship communicated through multiple languages and intertwined families during the dictatorship years reveal the layered foundations upon which future networking would build.

Klein 1971 Argentina 


\begin{abstract}
My connection to Ana and Sanni was as a result of their children attaching themselves to my children in an Argentine Jewish day camp in 1971. Ivonne and Guido spoke some English, my Rachel and Dan spoke some Spanish, all loved soccer and swimming, and so friendship among the children, led to friendship with both sets of parents. Ana and Sanni supported me when my Toba grammar was censured during the bad years in Argentina (Klein 1981). They served as my protectors in ways that Jews have found protectors for centuries.
\end{abstract}

The bubbe cookie episode, our last, shows how the distinctive cultural salience of food evokes connections among members of an ethnic group whose fractal potential for embodied connection had been sundered, disoriented and re-oriented by centuries of global immigration and exile. Together with the other stories we tell here, we show how each of the levels of our identity reiterates, harmonizes, fractalizes experience and knowledge. Klein's friends, Jewish, become Kane's friends as our (more often than not latent) Jewishness comes to the fore of our identity complex as gringa anthropologists. We might even be able to say that being Jewish opened some doors that our other identity bits clinging to gringo-hood might not have.

As we explore the fractal dimensions of gringo-hood in the sociolinguistic vignettes presented here, we move away from the use of 'gringo' as epithet evoking colonial ideology and toward the contrasting migrations and alliances that build upon and within its categorical imperatives.

\title{
Conclusion
}

The event thus enters culture as an instance of a received category, the worldly token of a presupposed type. Marshall Sahlins (1981:7).

Our personal narratives reflect the fractal patterns of sociolinguistic interaction. Furthermore, each narrative is a token of a type, which because of its difference from every other narrative, shows us the potential for defining diverse communicative events. Utilizing the definitions of gringo/a, we demonstrate the power of the word to project history into the present and myth into personal and professional experience. Finally, using these definitions as a heuristic device and ourselves as folkloric subjects, we have been able 
to maximize our analytic power of the socially situated experiences and the different forms of talk we encountered.

\section{References}

Adams, Abigail. 1999. "Gringas, ghouls and Guatemala: The 1994 Attacks on North American Women Accused of Body Organ Trafficking." Journal of Latin American Anthropology 4 (1): 112-33.

Diaz, Sofia. "1990. Bharata Natyam: A Hindu Fractal." Anthropology of Consciousness 1 (3): 19-23.

Eckert, Penelope and Sally McConnell-Ginet. 1992. "Think Practically and Look Locally: Language and Gender as Community-Based Practice." Annual Review of Anthropology 21: 461-490.

Eysturoy, Annie Olivia. 1990. "La Gringa in Chicano Literature. Universidad de Alcalá." http://www.recolecta.net/buscador/single page.jsp?id=oai:dspace. uah.es: $10017 / 4771$. Accessed on 2/10/12.

Favret-Saada, Jeanne. 1980. Deadly Words: Witchcraft in the Bocage. Cambridge: Cambridge University Press.

Gal, Susan. 2005. "Language Ideologies Compared: Metaphors of Public/ Private." Journal of Linguistic Anthropology 15 (1): 23-37.

Kane, Stephanie C. 1988. "Omission in Emberá (Chocó) mythography." Journal of Folklore Research 25 (3): 155-186

Kane, Stephanie C. 1992. "Race, sex work, and ethnographic representation, or, what to do about Loki's toast." Canadian Folklore canadien 15 (1): 109-117.

Kane, Stephanie C. 1994/2004. The Phantom Gringo Boat: Shamanic Discourse and Development in Panama. Washington D.C.: Smithsonian Institution Press. Second edition: Cybereditions.

Kane, Stephanie C. 2012. Where Rivers Meet the Sea: the Political Ecology of Water. Philadelphia: Temple University Press.

Kahn, Hilary. 2003. “Traversing the Q'eqchi' Imaginary: The Conjecture of Crime in Livingston, Guatemala." In Philip C. Parnell and Stephanie C. Kane, (eds.), Crimes Power: Anthropologists and the Ethnography of Crime, New York: Palgrave Macmillan :33-54

Klein, Harriet E. Manelis. 1999. “Narrative.” Journal of Linguistic Anthropology $9(1-2): 167-169$. 
Klein, Harriet E. Manelis. 1986. "Styles of Toba Discourse." In J.Sherzer \& G. Urban, (eds.), Native South American Discourse. The Hague: Mouton de Gruyter : 213-235

Klein, Harriet E. Manelis. 1978/1981. 2nd printing. Una Gramática de la Lengua Toba: Morfología Verbal y Nominal. Montevideo: Universidad de la República

Kroskrity, Paul V. 2001. "Identity.” In Alessandro Duranti, (ed.), Key Terms in Language and Culture. Blackwell Publishers: 106-109

Lemert, Edwin. 1975. "Social Pathology as excerpted. In Stuart H. Traub and Craig B. Little, Theories of Deviance. Itasca: F. E. Peacock Publishers.

Lévi-Strauss, Claude. 1967. Structural Anthropology. New York: Doubleday.

Lévi-Strauss, Claude. 1979. Myth and Meaning. New York: Schocken Books. Lindsay-Poland, John. 2003. Emperors in the Jungle: The Hidden History of the U.S. in Panama. Durham: Duke University Press.

Mandelbrot, Benoit B. 1977. The Fractal Geometry of Nature. New York: W.H. Freeman.

Nencel, Lorraine. 2001. Ethnography and Prostitution in Peru. London: Pluto Press.

Paredes, Américo. 1958. "With His Pistol in His Hand": a Border Ballad and its Hero. Austin: University of Texas Press.

Paredes, Américo. 1966. "The Anglo-American in Mexican Folklore," In Ray B. Brown, Donald M. Winkelman and Allen Hayman, (ed.), New Voices in American Studies. West Lafayette: Purdue University Press.

Paredes, Américo. 1977. “On Ethnographic Work Among Minority Groups: A Folklorist's Perspective.” New Scholar 7: 1-32.

Pfohl, Stephen. 1994. Second Edition. Images of Deviance and Social Control: A Sociological History. New York: McGraw-Hill.

Reuss, Richard A. 1974. "That Can't Be Alan Dundes! Alan Dundes Is Taller than That!": The Folklore of Folklorists. Journal of American Folklore 87 (346): 303-317.

Sahlins, Marshall. 1981. Historical Metaphors and Mythical Realities: Structure in the Early history of the Sandwich Islands Kingdom. Ann Arbor: University of Michigan Press.

Shelemay, Kay K. 1991. A Song of Longing: An Ethiopian Journey. Urbana: University of Illinois Press.

Starr, June. 2003. “The Anthropologist Accused.” In Philip C. Parnell and Stephanie C. Kane (eds.), Crimes Power: Anthropologists and the Ethnography of Crime. New York: Palgrave Macmillan: 77-98. 
Stoeltje, Beverly J., Cristie L. Fox and Stephen Olbrys. 1999. "The Self in 'Fieldwork': A Methodological Concern." Journal of American Folklore 112 (444): 158-182.

Acknowledgments: Thanks to all the many people and institutions who contributed to our fieldwork over the years. Special thanks to Moira Marsh for her contributions toward the folkloric framing of this work and for seeing us, the authors, as folkloric figures. Thanks too, Diane Tye and to our anonymous reviewers for their helpful comments on earlier versions. 